\title{
Sciendo
}

DOI: $10.1515 /$ aa-2018-0010

\section{The silent world of Reinaldo Arenas's novels}

Jana Waldnerová

Jana Waldnerová teaches Anglophone Literatures at the Department of English and American Studies, Faculty of Arts, Constantine the Philosopher University in Nitra, Slovakia. She is the author and co-author of several books, among the most prominent are The De/construction of Fictional Worlds (Dekonštrukcia fikčných svetov 2008), The Poetics of Humour (Poetika humoru 2011), and Six Chapters about Humour and Text (Šest' kapitol o humore a texte 2014), which reveal her main research interests: literary semiotics and humour.

\begin{abstract}
:
The paper focuses on the life and poetics of Cuban writer Reinaldo Arenas, an important representative of Cuban gay literature, who, due to his sexual orientation and eventual opposition to the Revolution, was silenced by the Cuban government and exposed to continual threats. His novels, which depict the hardship of and discrimination against ordinary people and gay members of Cuban society (for example Old Rosa and Farewell to the Sea), reveal also signs of the deep trauma that the writer suffered and its impact on his writing.
\end{abstract}

Cuban culture and its literature is still not so well known in contemporary Europe despite the great number of artists and writers who have always lived and worked there. The country has been tightly controlled since the advent of Fidel Castro's revolution and government. Reinaldo Arenas, the Cuban writer, dissident and later also emigrant, became one of the few voices to escape the Cuban information vacuum. Along with his novels, which were published and acclaimed outside Cuba, the power of the writer's angry voice grew also with the help of J. Schnabel's biographical film Before the Night Falls (2000). The film turned attention again towards the already deceased writer and his works.

The writer was born in 1943 into a poor peasant family in the province of Oriente, when Cuba was ruled by the Batista government. He grew up without his father and surrounded by women. The only man in the family was his grandfather. Owing to their poverty, it seemed impossible for Arenas to get an education. ${ }^{1}$ It was Castro's revolution that enabled Arenas to study at university where he could develop his extraordinary literary talent. Being a hero of the Revolution, Arenas could move from the uneducated countryside to the more intellectual 
environment of Havana. However, the consequences of the Revolution later had damaging effects on his life and writing career.

In his autobiographical book Before the Night Falls (1992), the writer remembers that not the presence of books, as one might expect, but their lack influenced the development of his imagination and creativity. In his grandfather's house, there were not any books and the quality of education in his village school was very poor. Arenas's fantasy grew and inflated to fill the emptiness and misery that accompanied his whole childhood. It was as if the cruelty, filth and wildness of the country and her beggarly people together with his grandmother's tales of demons and apparitions burned their image into his mind to create memory traces that would later form the writer's unique, baroque style. And then Havana, with her more intellectual environment, schools, libraries and worldly atmosphere challenged further the products of his pen.

Despite writing around 20 books and receiving a national award for the first one, only one of the writer's novels was published in Cuba - his second book Singing from the Well. ${ }^{2}$ Then, by government decree, both the author and his texts were declared improper for the Cuban people, which represented the enforced silencing and great trauma for any prolific writer probably the worst punishment. According to Fidel Castro, only those who supported the Revolution had rights in Cuba. Arenas did not belong among those people; he gave the state several reasons to silence him. In his texts, he constantly attacked and damaged the official, inviolable image of the country, of the Revolution and rebels. Being homosexual was also a great stigma in the Cuban macho culture and the author's decision to write about gay life and the situation in Cuba broke a deep-rooted social taboo and made him persona non grata in his homeland.

Arenas is usually regarded as a magical realist with a baroque style, ${ }^{3}$ which his novels confirm in many ways, ${ }^{4}$ or a postcolonial writer due to the homosexual themes that are either explicitly or implicitly present in his texts. ${ }^{5}$ Because of the situation in his country, Arenas had to spend most of his artistic life in forced isolation, and therefore his writing style evolved outside any literary group or canon. Unwanted in his homeland, his contacts with the cultural and artistic scene were cut, and the writer was officially regarded as an enemy of the state. Consequently, he could develop his writing skills and talents only by writing for the drawer and by debating with his fellow writers during secret meetings. Those friends were in the same situation, and secret meetings meant high risk, or they were undercover informants, and therefore not afraid. Writing was vital for Arenas; however, he did not consider belonging to any of the aforementioned categories. Instead, he regarded himself as a campaigner against 
Fidel Castro and his dictatorship that enslaved the Cuban people. His strong motivation was able to destroy many an obstacle to his creativity.

Although the fictional worlds of Arenas's novels possess an intriguing dreamlike quality with a variety of fantastic elements that interfere with the ontology of their protagonists as well as highly lyrical parts, the reader can easily identify post-revolutionary Cuba with many autobiographic elements. The writer drew a lot of inspiration from his life, as writing became his only therapy, keeping him sane in times of constant police persecution. Writing became also his only weapon in his personal war against Castro, a war that gradually transformed into his life mission. It was also the only way in which he could inform the outside world about the real situation on the island, where reality contrasted deeply with the material prosperity and liberty declared by the government. Actually, his writing represented the highest level of disobedience. Consequently, the writer was involuntarily silenced and his texts destroyed. For instance, he had to rewrite his novel Farwell to the Sea (1976) three times because the first manuscript was destroyed in 1969 by a friend out of fear of a possible police raid; the second version of the novel was found and destroyed by the police in 1971.

In some cases, with help from his friends and foreign visitors, Arenas had his texts smuggled out of Cuba to Europe and the USA. This was the only manner in which to get his words to readers and also how to inform the world about the situation on the island of Cuba, which Fidel Castro proudly called the Island of Freedom, although, the only freedom on the island was in that name. Abroad, Arenas's books were praised by both critics and readers, but such unexpected attention brought him many problems. Owing to his European success, news of which reached the Cuban secret services, the writer was imprisoned in 1974 for ideological deviation and publishing abroad without previous approval of the Cuban government. ${ }^{6}$

Farwell to the Sea finally reached a publisher and readers in Barcelona in 1982 after a dramatic and winding journey. The novel reveals a very unorthodox structure. Its text is divided into two parts that juxtapose two different streams of consciousness. The first of them belongs to the young wife of a young revolutionary who is also mother to a son. During a six-day family vacation, she recapitulates her life and marriage. Each day forms a chapter of that starts with her contemplation of the ocean, its colours and noises:

The ocean... blue... Not at first. At first, it's sort of sallow. Ashen, you might say... Although it's not ashen either. White, perhaps. But of white meaning transparent. White. And then - though, still, almost at first - it turns gray. Gray for a while. And then dark. 
Covered with even darker furrows, cracks in the water... Perhaps they're waves. No just mirages of water, and sun. (Arenas, 1986, p. 3)

Then, as the text goes on, she continues with her recollections of their previous, single life and tries to find out what happened to her marriage. Her memories are fragmentary; they appear and disappear suddenly while she is trying to make sense of their lonely vacations by the sea, where her husband neglects and avoids her as much as he does at home. There is only one woman with a teenage son in their neighbourhood, but the woman is mostly lonely, in the company of her infant son and thoughts. This part contains almost no dialogue, a feature that also foregrounds the final impression of loneliness.

The second part, which is her husband Hector's stream of consciousness, also starts with the ocean, but the man's perception is very different. He is not thinking about the ocean of colour, noise and water that he sees but about the infinity that the word implies for him. In his mind, the ocean represents the infinity of harassment, misery, blackmail, abstinence, despair and forced labour that fill his life. Then there is also the ocean of silence, fury, insults and weakness. Both parts of the novel follow a similar pattern to show how differently the two protagonists perceive the same situation, which is achieved by the juxtaposition of the thoughts of the two different individuals. In the woman's part, the loneliness and frustration of a wife who cannot understand what has happened to her marriage or where its passion and love disappeared to leak out from the layers of words. The man's part fires off streams of words that speak about the suppressed fury, everyday poverty, downfall of society and hypocrisy that is vital for those who are different and want to survive. Along with that Hector reveals also his lost belief in the Revolution, which has replaced his initial enthusiasm.

The second part, Hector's stream of consciousness, is divided into a similar number of chapters as the first one but they are called cantos due to their form. The thoughts forming this part follow lyrical patterns that eventually change into prosaic paragraphs, or there are groups of words arranged to create certain shapes, columns and lines crossing pages of the book. The example below shows one formation that resembles a heart-monitor readout:

$$
\begin{gathered}
\text { establishing the death penalty } \\
\text { in special cases } \\
\text { for adults } \\
\text { of } 16 \text { years of age or more } \\
\text { has been given virtually } \\
\text { unanimous }
\end{gathered}
$$




approval
in all meetings
held
through-
out
the
length
and
breadth
of
the
land (ibid., p.337)

The short column that follows reads: "National Clock Radio - Tuesday, the 25th of September, 1969 ..." (ibid., p. 337). and thus confirms the meaning of the shape above. In fact, the text is part of the news that was broadcast on the National Clock Radio and which implicitly spoke about further repression, further persecution and further executions in the country, which is the implicit explanation of the heart-monitor readout of a dying heart.

Another of Arenas's novels, Old Rosa (1989), is more traditional, with its story, or rather two stories, dividing the book into two parts. Arenas dedicated this text in memoriam to his friend, the writer Nelson Rodriguez. Rodriguez had died in a forced labour camp, which was a common fate of opponents of the regime at that time. The two parts of the novel present two stories of the elderly, toil-worn peasant Rosa and her son. The first part starts with the death of its main protagonist, Rosa, who dies in a fire she had set in her own house. The text continues with a retrospective of her life which starts with her marriage and her transformation from a beautiful young woman into the strong, despotic ruler of her small world.

Rosa's character represents strong Cuban countrywomen, devoted Catholics, who fight for each piece of land and each grain of their harvest. Rosa lives according to her simple personal philosophy that might be expressed as: if you give God his due, then you will receive everything you deserve. However, this philosophy is incompatible with the new era and with Cuban communist ideology. The new state of affairs that arose with the government's undermining of traditional social relations brings fatal disruption to Rosa's life. She is not able to grasp that the Revolution changed the old world as well as their traditional compact with 
God. She can neither understand that Castro has replaced God, and now he says that the results of her hard work are not hers anymore because they belong to the Cuban people, and her farm as well. Her greatest personal disappointment comes when she finds her youngest son in his friend's arms. She is destroyed because her son has broken the supreme cultural and religious laws of the country, the laws of the macho culture.

The macho culture, which is typical for states of Latin America including Cuba, values manhood, aggressiveness, male domination, female subordination and submission. Machismo came as a consequence of 400 years of Spanish-Catholic colonial dominance and the mixing of the traditions and customs of African people, which appeared on the island with slavery. Machismo started with the arrival of Cortes's settlers, men of strong and strict belief who neither understood women nor marriage. Their direct influence can be seen in certain local customs and conceptions, in the overestimation of men, in the perception of women as mere vessels for reproduction, in social double standards that people gradually absorbed so deeply that they became social norms. Consequently, any digression from those standards means at least a certain measure of social condemnation in these environments. In this context, the social approach to gay people appears as a problem of male identity because male individuals have to incessantly confirm their strength to ensure the "expected public image". ${ }^{7}$ Any exhibition of effeminacy or weakness could tragically disturb such an image in the public perception. In the case of the male population, it means an either/or situation, in other words, anything that opposes the macho stereotype leans towards female values and therefore is regarded as highly inappropriate or impermissible for a man.

After Castro's revolution, homosexuality in Cuba was regarded as unethical, and preexisting homophobia was turned into an institutionalized political programme. A man became homosexual only if he accepted a submissive role. Owing to this conception, men whose behaviour was in contradiction to the ruling macho conception became easy targets for police persecution. ${ }^{8}$ That was also the reason why one short moment changed Arturo's status from a beloved son and his mother's pride into family shame.

Arturo's life after the fire is depicted in the second part of the novel. His orientation sees him sent to a labour camp in a sugarcane mill. The work is monotonous and physically very demanding, almost unbearable. Arenas himself experienced the same. He was sentenced to a labour camp under similar circumstances. There he had to cut sugarcane in the fields as part of his rehabilitation as well as write a book about the positive effects of that experience on his personality, which meant his reformation from a gay to a straight man. In his autobiography, Before the Night Falls, Arenas compares the situation in the camp to the worst hell because 
men worked there like slaves, lived there like slaves and had similar rights. According to him cutting sugarcane was the worst possible punishment because in the past the Indians and blacks chose to die rather than cut. In that time he felt really very sorry for his young inmates:

I was one among hundreds of recruits. It was perhaps more pathetic to see them there than to see myself because I had already lived some years of splendor, even if underground, but those young men, sixteen and seventeen years old, were treated like beasts, had no future to hope for, nor a past to remember. Many would hack their legs or cut their fingers off with their machetes. They would do absolutely anything to be relieved off working in the sugar fields. (Arenas, 1994, p. 187)

Arturo is a man with no fond memories and no future. He is also the only concrete character in the second part of the novel. After a police raid in Havana, he is sentenced to a labour camp with other, mostly gay, men. In that time he is a young boy on the verge of adulthood, almost innocent. There they live in shabby huts under the machine guns of the guards. Besides everyday hard labour in the sugarcane fields, almost everything is forbidden in the camp. While writing this text, Arenas found a lot of inspiration in his own life, and this novel also became his testimony to the situation in the country and the consequences of the post-revolutionary homophobia that led to the criminalization of homosexuality. Men like Arenas and his character Arturo were either interned in rehabilitation camps or imprisoned and exposed to unceasing abasement and torture, although sexual orientation was the only difference between the incarcerators and their prisoners.

Although this novel is more traditionally constructed than the previous one, both reveal either a lack of dialogue or its complete absence. There are neither dialogues between Arturo and his prison mates nor between Arturo and his guards, as well as there being almost no dialogue in Farwell to the Sea.

Looking at the author's other works reveals similarities also with regard to this aspect of his writing. For example, there are only a few dialogues in The Doorman (1987) ${ }^{9}$ and the situation is more or less similar in The Palace of White Skunks (1990). This lack is so significant that it might even constitute one of the writer's idiosyncrasies, which probably, we can guess, evolved from his frequent isolation into which he was forced as a writer and citizen of Cuba too. For example, Arenas spent two years hiding in Lenin Park during the period he was working on the third version of Farwell to the Sea. Then his encounters with other people were limited to rare secret visits by his most reliable friends, who provided him with food, clothes 
and medicine that enabled him to survive. His only real company was Homer's Iliad, and that is why Helen of Troy emerges on the pages of the book to haunt its female protagonist.

The police were only able to capture Arenas after two years of searching, having arrested his friends. But this period of isolation was not the only one in his life; there were more cases in which he was forced to hide again or was imprisoned so his personal and artistic interaction with his environment was curtailed. Due to these facts, the significant lack of dialogue in Arenas's novels appears to be a direct outcome of the trauma he experienced, when as a person and as a writer he was surrounded by silence so often and for and such long periods. This quality of Arenas's poetics along with his themes and characters capture the writer's stories including his own personal one, and speak about an author whose life and work were often surrounded by a sea of enforced silence due to his political and personal incompatibility with the government in Cuba.

\footnotetext{
Endnotes: In that time, $43 \%$ of adults were illiterate (Leiner, 1994, p. 15).

${ }^{2}$ Published in 1967 as Celestino antes del alba.

${ }^{3}$ More Botoso, 2011; Balerston, 2000.

${ }^{4}$ For example, there is a dinosaur and Helen of Troy in Farwell to the Sea, and speaking pets in his American novel Doorman (1991)

${ }^{5}$ More Morales-Diaz, 1996; Vickroy, 2005.

${ }^{6}$ More Arenas, 1994.

${ }^{7}$ More Ellis, 1993.

${ }^{8}$ More Leiner, 1994.

${ }^{9}$ The novel was written during the writer's US exile.
}

${ }^{1}$ According to research from 1950, people in the Cuban countryside lived in very primitive conditions in huts with palm-leaf roofs and clay floors; two thirds of them were without electricity or running water.

\section{Works cited:}

Arenas, R. 1976. Farwell to the Sea. A novel of Cuba. Harmondsworth, Middlesex: Penguin Books Ltd.

Arenas, R.1989. Old Rosa. New York: Grove Press.

Arenas, R.1991. The Doorman. New York: Grove Press.

Arenas, R. 1993. The Palace of White Skunks. New York: Penguin Books Ltd.

Arenas, R.1994. Before Night Falls. Harmondsworth, Middlesex: Penguin Books Ltd.

Balderston, D. - Gonzales, M. - López, A. 2000. Encyclopedia of Contemporary Latin American and Caribbean Cultures: A-D. Vol. 1. New York: Routledge. pp. 49-52.

Botoso, A. 2011. "O realisimo maravilhoso no romance o Mundo alucinante de Reinaldo Arenas“. In: RevLet Revista - Virtual de Letras v. 03, nº1, pp. 200-218. 
Ellis, J. 1993. Homosexuality in Cuba: Revolution within the Revolution. Available at: $<$ http://www.hartford-hwp.com/archives/43b/172.html>.

Epps, B. 1995. "Reinaldo Arenas, Fidel Castro and the Politics of Homosexuality". In: Journal of the History of Sexuality: Vol. 6, No. 2, pp. 231- 283.

Leiner, M.1994. Sexual Politics in Cuba. Machismo, Homosexuality and AIDS. San Francisco: Westview Press.

Morales-Diaz, E. 2006. "Calibanesque Revolution in Rinaldo Arenas' Writing”. In: Postcolonial Text, Vol. 2, No 2. Available at:

$<$ http://postcolonial.org/index.php/pct/article/view/258/772>.

Morales-Diaz, E. 1999. Caliban, and Postcolonial Discourse. Amherst NY: Cambria Press.

Vickroy, L. 2005. The Traumas of Unbelonging: Reinaldo Arenas' Recuperations of Cuba. In: MELUS, Vol.30, No 4, pp. 109-128.

Waldnerová, J. 2007. “A message of freedom on the island of liberty”. In: Drogi do wolnošci w kulturze Europy Šrodkowej i Wschodniej 1956 - 2006. - Varšava: University Press, pp. 193-199.

Department of English and American Studies, CPU Nitra, Stefanikova 67, Nitra, Slovakia e-mail: jwaldnerova@ukf.sk 